\title{
IMPLEMENTATION OF FARM MANAGEMENT AND FINANCIAL FEASIBILITY EVALUATION OF SHALLOT (ALLIUM ASCALONICUM L.)
}

\author{
Hardana Andrean Eka*, Pariasa Imaniar IImi, Riyanto Sugeng, Pratiwi Destyana E. \\ Faculty of Agriculture, University of Brawijaya, Malang, Indonesia \\ *E-mail: andrean@ub.ac.id
}

\begin{abstract}
The research objective ware (1) to analyze the financial feasibility of farmers who cultivated shallots in research area, and (2) to describe the management of shallot farm management in the highlands, especially in Batu City, East Java. Determination of research location of the study was conducted purposively, namely in the Junrejo Village, Junrejo subdistrict, Batu City. The method of retrieving farmer respondents was carried out using a probability sampling approach with a simple random sampling method. Data analysis methods that are suitable for research on farming analysis and marketing of shallots, based on an approach are included in the method of quantitative data analysis for farming income analysis and qualitatively for management analysis of shallots farming. The average commodity production of shallots is 14.6 tons / ha, with the calculation of the average total cost of farming including fixed costs (equipment depreciation, land tax, and land rent) as well as variable costs (seeds, fertilizers, pesticides, and labor) ) issued 54,010,236.2 IDR/ha and the average selling price of IDR. 7,000. Then the calculation of farm income in the study area was IDR 47,916,916.2 / ha, so the data was said to be profitable onion farming. The management of shallot farming in Junrejo Village, Junrejo Subdistrict, Batu City has been running according to the field implementation, but there are several management functions that must be given attention such as controling functions which are more concerned in field implementation especially with regard to farming input applications.
\end{abstract}

\section{KEY WORDS}

Farm management, financial feasibility evaluation, farming, agribusiness.

Management capability in agribusiness activities is important to be applied to various agricultural commodities. This management activity is needed because it is not merely a way of life in managing farming. In its meaning more than that, the process of implementing it in a company is needed in an effort to avoid the ups and downs in agribusiness (Rahardi, F., et al, 2000).

Handling shallot commodities needs optimal application in agribusiness management. The implementation of integrated management is needed because the commodity of shallots has many benefits and has high economic value. The consumption of shallots in Indonesia per capita per year reaches 4.56 kilograms or 0.38 kilograms per capita per month. The high demand for shallots that continues to increase does not only occur in the domestic market, but also has the opportunity to export (Directorate General of Horticulture, 2012)

Integrated management of agribusiness management is carried out to increase the production of shallots both in quantity and quality. Agribusiness management activities ranging from business planning, provision of facilities and infrastructure, crop cultivation, to handling the results and marketing are carried out in an integrated and mutually supporting manner. So that in this case a management is needed that can summarize natural factors, capital, labor, and technology with the factors of facilities and infrastructure and marketing.

In the implementation of agribusiness management management, one of them is the financial feasibility of shallots. The shallot farming in the highlands during the rainy season also needs to be known, given the high risk of failure. This activity is to find out whether the farming activities are still profitable and can provide incentives for farmers to do shallot farming in the highlands in the rainy season in a sustainable manner. In general, the analysis of shallot farming has only been done for the lowlands (0-500 masl) (Nurmalinda et al, 1992; 
Soetiarso and Madjawisastra, 1993; and Nurmalinda et al. 1994), while for the highlands there is still little.

Based on the introduction above, the authors are interested in conducting research on "the application of farming management and evaluating the financial feasibility of shallots in rural Indonesia". The research objective was to (1) analyze the financial feasibility of farmers who cultivated shallots in the study area, and (2) describe the management of shallot farming in the highlands, especially in Batu City, East Java. Therefore, it is expected that the analysis of financial feasibility and management of shallots farms cultivated by farmers in the research area can be formulated as alternative actions in the form of technological improvements and appropriate policies to increase shallot production, which in turn can increase farm income.

\section{METHODS OF RESEARCH}

Determination of the location of the study was conducted purposively, namely in the Village of Junrejo, District of Junrejo, Batu City. The consideration of determining the location of this study is based on data from the Agriculture and Forestry Service of Batu City (2012). The research area is the center of commodity production of shallots with the achievement of land area and the largest production, which is 65 ha with a production of 665 tons in Batu City. The method of retrieving farmer respondents was carried out using a probability sampling approach with a simple random sampling method. The number of samples obtained based on the taking of the parel formula was 37 people (from a population of 356 people) who were in the NICE Farmers' Association.

Data analysis methods that are suitable for research on farming analysis and marketing of shallots, based on an approach are included in the method of quantitative data analysis for farming income analysis and qualitatively for management analysis of shallots farming.

Based on a review of previous research conducted by Zalukhu (2009), the total cost of farming production can be calculated using the following formula:

$$
\mathrm{TC}=\mathrm{TFC}+\mathrm{TVC}
$$

Where: $\mathrm{TC}=$ The total cost of farming shallots; TFC = Total fixed costs for onion farming; TVC = Total variable cost of farming onions; Analysis of Total Farming Revenues.

The total receipt of shallot farming is the value of money obtained by farmers from the sale of the production of red onion farming at the price of the unit. The amount of income obtained by farmers can be calculated using the formula:

$$
\mathrm{TR}=\mathrm{P} \times \mathrm{Q}
$$

Where: $\mathrm{TR}=$ Total receipt of onion farming; $\mathrm{P}=$ Selling price of shallots; $\mathrm{Q}=$ Total onion production.

Based on previous research conducted by Utami (2009), the amount of total farm income can be calculated using the formula:

$$
\Pi=\mathrm{TR}-\mathrm{TC}
$$

Where: $\Pi=$ Income of onion farming; $T R=$ Total Acceptance of onion farming; $T C=$ The total cost of farming shallots.

After that, according to Soekartawi (2002) to identify the financial feasibility analysis, namely R / C, which was formulated as follows:

$$
R / C=T R / T C
$$

Where: $T R=$ Total Revenue (total receipt); $T C=$ Total Cost (total cost); If $R / C \geq 1$, then the farming is said to be feasible; If $R / C<1$, then the farming is said to be inappropriate. 


\section{RESULTS AND DISCUSSION}

Farming analysis is done by calculating the income level of shallot farming one planting season. In this analysis find out the amount of costs incurred by the farmer, such as the cost of production input facilities, labor costs, equipment depreciation costs, land tax costs, and land rental costs. In more detail, this will be discussed in the following explanation.

The total cost of farming production is the cost used by farmers in the implementation of the production process, the amount of which is obtained from the sum of fixed costs and variable costs. Both types of costs represent all the sacrificial values of various production inputs that are issued during the production process. The calculation of production costs for shallots consists of only fixed costs (not calculating capital interest) and variable costs, because the capital used by respondent farmers to manage shallots comes from personal capital, not in the form of loan capital.

Table 1 - Average Production Costs of Shallot Farming in the Research Area

\begin{tabular}{cccc}
\hline \multirow{2}{*}{ No } & Component & Average cost \\
\cline { 3 - 4 } & Fix Cost & $(\%)$ \\
1. & Tools Depreciation & $124.349,43$ & 6,19 \\
2. & Farmland Tax & $175.414,12$ & 8,72 \\
3. & Rent land & $1.710,73$ & 85,09 \\
& Total fix cost & $2.010 .488,87$ & 100 \\
B. & Variable cost & & 24,13 \\
1 & Seed & 12.545 .000 & 13,49 \\
2 & Fertilizer & $7.014 .481,49$ & 13,07 \\
3 & Pesticide & $6.794 .288,2$ & 49,31 \\
& Labor & $25.645 .977,6$ & 100 \\
\hline
\end{tabular}

Fixed costs on shallot farming are relatively fixed costs and do not depend on the amount of production obtained in farming. Components for fixed costs in this study consist of equipment depreciation costs, land tax costs, and land rent. In Table 1, it is also explained that the total average of the fixed costs of shallot respondent farmers is IDR. 2,010,488.87. Variable costs are costs which are used up in one planting season and affect the size and size of the production of shallot farming that will be produced. Raw material is a variable that can change the amount and value in the production process. The higher the production, the more raw material needs are needed. Based on Table 1, it can be seen that the total use of the average variable costs for the respondent farmers in shallot farming is IDR. $32,446,014.7$. Variable costs in shallot farming consist of various components such as seeds, fertilizers, pesticides, and labor.

Total revenue in shallot farming is the value of money obtained from the sale of the farm products. The amount of acceptance in shallot farming is influenced by the size of the production produced, where the greater the production, the greater the income that will be obtained by the farmer. If the selling price is high and followed by a high amount of production, then the revenue obtained will be even greater, and vice versa.

Table 2 - Average Revenue of Shallot Farming

\begin{tabular}{ccc}
\hline No & Description & Value \\
\hline 1 & Average of Shallot Production $($ ton $/ \mathrm{ha})$ & 14,6 \\
2 & Average of Shallot Price $(\mathrm{Rp} / \mathrm{kg})$ & 7000 \\
\hline & Total of revenue average $(\mathrm{Rp} / \mathrm{kg} / \mathrm{ha})$ & $101.926 .432,4$ \\
\hline
\end{tabular}

The production of each land between farmers who cultivate shallots varies depending on the size of the land and the production facilities and infrastructure used. The average total production produced by local farmers in shallot farming reaches 14.6 tons / ha with a selling price of IDR. 7,000/ kg. Pricing obtained by farmers from marketing institutions is based on 
market prices affected by imported onions from India and China in several regions in Malang. Local red onions can compete because the quantity of imported shallots is decreasing in quantity in the market. In addition, in terms of quantity superior in terms of taste, the aroma is sharp; the skin color of the tuber is dark red, and crisp. Based on the calculation of the quantity of shallot production per hectare multiplied by the average selling price of shallots prevailing at the time of the study, so that for the total average income of respondent farmers in the study area it reached IDR 101,926,432.4 / kg / ha.

Farm receipts have an influence on the size and size of the income of farmers who cultivate shallots. This is because the income earned by the farmer comes from the difference between total revenues and the total production costs incurred during the farming process. So from that by knowing the amount of revenue and total costs that have been incurred by the respondent farmers, so that it can be seen also the amount of income earned. The average income obtained by farmers at one planting season can be seen in Table 3 below.

Table 3 - Average Income of Red Onion Farming

\begin{tabular}{ccc}
\hline No & Uraian & Nilai \\
\hline 1 & Rata - rata Penerimaan Bawang Merah & $101.926 .432,4$ \\
2 & Rata - rata Total Biaya Bawang Merah & $54.010 .236,2$ \\
& Total Rata - rata Penerimaan (Rp/kg/ha) & $47.916 .916,2$ \\
\hline
\end{tabular}

Based on Table 3, by making a farm analysis it can be calculated mathematically in trying on one hectare of shallots. Farming is said to be profitable if the difference between revenue and expenditure is positive. Based on the calculations, it can be seen that the total average income obtained by farmers who practice shallots in the study area is Rp. $47,916,916.2$ / ha, so that it can be said to be profitable.

The ratio of revenue to expenditure is the profit rate of onion farming. The $\mathrm{R} / \mathrm{C}$ ratio for total costs is greater than 1 , so it can be said that farming is carried out favorably by the farmer manager. The value of $t$ calculated $R / C$ ratio over the total cost is 1.9. Based on these results from the test, onion farming in Junrejo Village has a value of the ratio of receipts to expenditures that is greater than 1 . This condition is one indication that onion farming in research locations is relatively profitable.

The initial preparation of planting shallots must begin with the opening and processing of the land perfectly in order to produce optimal shallot production. Opening and processing land is not a difficult activity. The land of farmers planted with shallots needs to be cleaned first from grass and various wild plants by using mechanical equipment such as hoes or using hands manually. The results of cleaning grass and wild plants are then burned outside the field. The purpose of land clearing is to eliminate grass as well as to prevent pests and diseases.

If the land used to plant shallots by local farmers has been established, for the first action is to determine the area unit and spacing pattern. The planting distance for shallots which is generally applied by respondent farmers in the study area is $15 \times 15 \mathrm{~cm}$.

The red onion seeds in Junrejo Village are from seedlings of Philippine red onions imported by way of imports from the Philippines. In general, farmers in the research area get onion seeds from marketers. Farmers still use seeds from abroad, because they are generally in accordance with local conditions. In addition, it can produce a good and optimal onion production.

Planting is done at the end of the rainy season. The way to plant them is to peel the skin of the bandage first and separate the cloves. To speed up the release of shoots, before planting the seedlings are cut to $1 / 3$ part. Seeds are planted standing on beds until the surface of the incision is covered by a thin layer of soil.

The actions to preserve onion in the research location are as follows:

Watering can use a spout or sprinkler, or by flooding the water around a bed called the system. Irrigation is carried out regularly in accordance with the needs of plants, especially if there is no rain. 
This activity aims to eliminate wild plants that grow around shallots, regulate the humidity of the garden, prevent pests and diseases, and reduce competition between shallots and weeds in getting water and nutrients from the soil. done together at the time the plant is 21 days old.

Stitching is carried out by replacing dead plants with new onion seeds. The replanting process is still carried out as long as the core plant is not yet two weeks old.

Fertilizing shallots is done so that plants are able to produce with optimal results and add and restore nutrients to the soil. The type and dosage of fertilizer used in onion farming in Junrenjo Village are using organic fertilizers and inorganic fertilizers. Fertilizers given are animal fertilizers with a capacity of 8-10 tons / ha, while inorganic fertilizers with urea doses of $100 \mathrm{~kg} / \mathrm{ha}$, ZA $200 \mathrm{~kg} / \mathrm{ha}$, TSP / SP-36 $250 \mathrm{~kg} / \mathrm{ha} . \mathrm{KCl} 150 \mathrm{~kg} / \mathrm{ha}$ (according to soil fertility).

Pests and diseases can attack all parts of the plant, starting from the roots, stems, and leaves. Pest control is carried out depending on pest and disease attacks. Pests that give up onion are caterpillar, leaf caterpillar, armyworm, aphids, and root nematodes. How to control pests in shallots in Junrejo village using furadan pesticides sprinkled during processing of land. Pests found on red onions are caterpillar onions and trips. Disease control in red onions uses adhesives and antracol. Adhesives are used to control molten disease (fusarium wilt), and antracol is used to control anthracnose.

Harvesting is done if the tuber is about 60 years old, enough, the leaves begin to turn yellow, how to remove the whole plant carefully so that there are no tubers left behind or abrasions. For 1 (one) hectare well-cultivated shallots, 10-15 tons can be produced (Rukmana, 1995). In the study area for the Philippines varieties yielded up to 14 tons / ha more than the average productivity produced by local farmers

In onion farming activities by respondent farmers in the research area are selective in determining / determining the parts in the organization as well as the tasks and functions of each that is in the organization. The local farmer institution, namely the NICE farmer group, can determine the position according to the expertise / ability possessed by the respondent's farmers. Farmer groups as a forum for organization in the hope that they can cooperate between farmers and other farmers.

In respondent's onion farming, they try optimally to increase production both in quality and quantity. Local farmers with spell farming from Batu's agriculture and forestry service were given guidance (counseling) and a comparative study was held to other areas followed by shallot farmers to increase their experience and knowledge, especially in onion farming.

In the implementation of the control, the respondent farmers were very careful in conducting farming and if necessary made corrections of the results of the work carried out so that what was being carried out by group members could be directed or guided to the road that was in accordance with the aims and objectives planned and determined by group. This activity was carried out by farmers on shallot respondents in Junrejo Village so that farming carried out by farmer groups could be successful and in accordance with group expectations.

The steps that are generally carried out by farmer groups on shallot farming in the study area include:

- Planning by farmers can be structured in onion farming so that it can produce the quality and quantity of shallots, so it can compete with shallots from other regions;

- Provision of inputs for fertilizers and pesticides must be in accordance with the prescribed dosage so that the shallot plants produce maximally by issuing minimum costs.

\section{CONCLUSION AND SUGGESTIONS}

The implementation of delay selling activity in rice farming business was conducted by Rice Milling Unit (RMU) managed by GapoktanMutiaraTani. This unit provides mill and storage for farmers who want to delay their selling. Rice storage can be done partially so that farmers feel safe and flexible when they want to sell or take their grains. Furthermore, it is supported by warehouse facility with the capacity reaching 10 tons. 
Agribusiness development in rice farming business with delay selling activity gives more benefits compared to non-delay selling activity. Regarding total cost, delay selling actors have higher cost than those non-delays selling but the difference of rice selling price per kilogram makes delay selling actors obtain more profit than those non-delays selling. Agribusiness development was also conducted by farming Business Corporation in which the farmers (i.e. farmers group MutiaraTani) in Selodakon Village runs it. As a start, pilot project with 10 hectare rice field was applied with irrigation technique starting from breeding to postharvest.

Suggestions:

- As supporting facility, the capacity of grain storage in Gapoktan warehouse can be enlarged by expanding storage place and area of grain drying to accommodate the needs of seven farmer groups in order to participate in delay selling activity;

- The government can support the sustainable of this program especially for marketing aspect by cooperating GapoktanMutiaraTani with Bulog institution in Jember district.

\section{REFERENCES}

1. Agriculture Research and Development Berau. (2005). Sugar Cane in Indonesia. Agriculture Berau. Jakarta.

2. Bernatonyte, D. Burksaitiene, D. \& Rimiene, K. (2013). Trade Specialization Pattern of Lithuania. Economics and Management: 2013. 18 (4).

3. Bernatonyte, D. \& Normantiene, A. (2009). Estimation of Trade Specialization: the Case of the Baltic States. Ekonomika-Engineering Economics (2).

4. Burger, K. Kameo, D. \& Sandee, H. (2001). Clustering of Small Agro-Processing Firms in Indonesia. International Food and Agribusiness Management Review, 2(3/4): 289-299.

5. Caporale, G. M. \& Sova, R. (2015). Trade Flows And Trade Specialisation: The Case of China. Working Paper No. 15-07.

6. Churmen, Imam. (2001). Save sugar industry in Indonesia. Millenium Publisher. Jakarta.

7. Dachliani, D. (2006). Demand of sugar import on 1980-2003 in Indonesia. (Thesis). Faculty of Economic. Diponegoro university. Semarang.

8. Delroy Anthony Armstrong.(2004). The Potential Impact Of Trade Policychanges On Caribbean Sugar. B.S., Louisiana State University.

9. Dipl.-Ing. Dieter Bahndorf, Udo Kienle. (2004). World Market of Sugar and Sweeteners. OECD-FAO Agricultural Outlook 2016-2025, OECD Publishing, Paris

10. Firmansyah, (2008). The Position of Competitiveness and Specialization Trading of Tealndonesia in Facing Globalization.Brawijaya. University. Malang.

11. Gaynor, P.E., and R.C. Kirk Patrick.(1994). Tome Series Modeling and Forecasting in Business and Economics. New York, Mc Graw hill.

12. Haley, Stephen.2013. World Raw Sugar Prices The Influence of Brazilian Costs of Production and World Surplus/ Deficit Measures. United States Department of Agriculture

13. Matsumura, Kanichiro.(2010). Demand and Supply Structure for Food in Asia. Sustainability 2011, 3, 363-395; doi:10.3390/su3020363

14. McConnell, Michael; Erik Dohlman; Stephen Haley. (2010). World Sugar Price Volatility Intensified by Market and Policy Factors

15. McCormick (2009). Supply and demand: sink regulation of sugar accumulation in sugarcane. Journal of Experimental Botany, Vol. 60, No. 2, pp. 357-364

16. Rumánková, Lenka and Smutka, Luboš. (2013). Global Sugar Market - The Analysis Of Factors Influencing Supply and Demand. Volume LXI. No. 2, pp. 463-471

17. Sa'diyah, C. (2014). Factors that influence of economic performance for crystal sugar in Indonesia. (Thesis). Faculty of Agriculture. University of Brawijaya. Malang

18. Sinaga, N. (2006). Model Econometric Aplication. IPB Post Graduate. Bogor.

19. Susila, Wayan.R dan Bonar M. Sinaga. (2005). Analysis of Sugar Industry Policy in Indonesia. Jurnal Agro - Ekonomi Volume 23 No. 1, page 30-53.

20. Xue Xu and Hailong Xia.(2014). Analysis and Outlook of China's Sugar Industry Development. Proceedings of Selected Articles of 2013 World Agricultural Outlook. 